\title{
A COMPANHIA DE JESUS NO SÉCULO XVI E O BRASIL
}

\author{
Paulo Romualdo Hernandes \\ Universidade Federal de Alfenas - UNIFAL-MG
}

\section{RESUMO}

Neste artigo é relatado o resultado da pesquisa sobre a Companhia de Jesus e sua inserção no Novo Mundo, no Brasil do século XVI. Seguindo os passos de alguns jesuítas, como Inácio de Loyola, Manoel da Nóbrega e José de Anchieta, pretende-se, começando com Loyola, apresentar a formação da Companhia de Jesus, os primeiros companheiros e sua ligação com o rei Dom João III de Portugal. Manoel da Nóbrega deu os primeiros passos para o estabelecimento da Companhia de Jesus no Brasil e começou com os primeiros trabalhos. Com José de Anchieta, por meio, sobretudo, de seu teatro, embrenha-se neste estudo, nos encontros e desencontros de culturas, na tentativa dos padres de tornar cristãos e, sobretudo, católicos os homens do Novo Mundo.

Palavras-chave: educação jesuítica; Brasil-Colônia; Inácio de Loyola; Manoel da Nóbrega; José de Anchieta.

\section{THE SOCIETY OF JESUS OF CENTURY XVI AND BRASIL}

\section{ABSTRACT}

In this article is reported the result of the research on the Society of Jesus and its insertion in the New World, in Brazil of Century XVI. Following the footsteps of Jesuits such as Ignacio de Loyola, Manoel da Nobrega and Jose de Anchieta, it is our intention, starting with Loyola, to introduce the Society of Jesus, the first companions and its connection with King Dom João III of Portugal. Manoel da Nóbrega took the first steps to establishing the Society of Jesus in Brazil and started off its works. José de Anchieta, mainly through his theater, makes us penetrate in the similarities and differences between cultures, through the priests' attempt to turn man of the New World, Christian or, above all, Catholic.

Keywords: Jesuit Education; Colonial Brazil; Ignácio de Loyola; Manoel da Nóbrega; José de Anchieta.

\section{INTRODUÇÃO}

Apresenta-se neste artigo um estudo sobre encontros e desencontros de culturas. A cultura europeia do final do período medieval e início da Idade Moderna e a brasileira do século XVI. Para este estudo, à moda de Bakhtin, que nos revelou muito sobre a cultura popular na Idade Média e no Renascimento a partir da obra de Rabelais, Gargântua e Pantagruel (2009), também foram selecionados importantes personagens históricos da Companhia de Jesus: Inácio de Loyola, Manoel da Nóbrega e José de Anchieta, seus discursos e suas obras, que nos podem fazer ver aspectos importantes da formação social, cultural e educativa no Brasil quinhentista.

Este estudo inscreve-se na História da Educação brasileira que, segundo Maria Cristina Piumbato Innocenti Hayashi (2008, p. 203), "é um campo pouco pesquisado na área de educação". Está circunscrito em um período da história da educação brasileira em que há uma lacuna de pesquisas e publicações, sobretudo em se tratando do século XVI. Basta, como prova dessa assertiva, relatar que no III Congresso da Sociedade Brasileira de História da Educação, realizado em Curitiba, havia apenas três estudos sobre Brasil 
Colônia, entre 394 trabalhos apresentados. Na ANPED, nos anos 2000, 2001, 2002, 2003, 2004, no grupo de trabalho em História da Educação, apenas um trabalho foi apresentado sobre o Brasil Colônia (FERREIRA JÚNIOR; BITTAR, 2007, p. 94). Uma das razões para que o período colonial brasileiro esteja sendo pouco estudado seria porque já o teria sido por importantes especialistas, como Fernando de Azevedo, Sérgio Buarque de Holanda, Capistrano de Abreu, Serafim Leite, entre outros. O que faz parecer que tudo já foi dito e escrito de forma apropriada e definitiva. Nada mais seria novidade. Com esse argumento, o grupo de trabalho da ANPED recusou o trabalho Infância, catequese e aculturação no Brasil colônia, em 2002, dizendo que, apesar de o trabalho ser interessante, "no qual se observa uma evidente capacidade discursiva e analítica do autor e ter o mérito de tratar de um período pouco estudado, não traria novidades para o campo"; afinal, basear-se-ia em cartas jesuíticas (BITTAR, 2006, p. 20). Outra razão, também preocupante, seria que, após a abertura militar no Brasil e, sobretudo, com a chegada por aqui dos modismos pósmodernos, como o fim da história, o fim das narrativas históricas e das ideias de totalidade e o fim do marxismo, os estudos históricos estariam partindo, segundo Warde (apud BITTAR, 2006, p. 8), para um "escancaramento novidadeiro [...] e assimilação inadvertida de novos problemas, na ilusão de que, em sendo novos, pelo menos são melhores do que os anteriores". Nesse mesmo artigo, Sanfelice enfatizava que "aderir ao 'novo', divulgar o 'novo', sem ter o domínio crítico epistemológico do 'velho' que estaria sendo superado pode ser descaso, ingenuidade ou mesmo intencionalmente a opção por outros interesses. É, sem dúvida, uma postura novidadeira" (Ibidem, p. 8).

Não há estudos suficientes sobre um período que tem muito a ser estudado em novos documentos ou releituras de documentos e muito a ser revisto, inclusive as camadas discursivas construídas por estudiosos renomados, como Fernando de Azevedo, Serafim Leite, sobre os documentos quinhentistas; sobre as cartas dos jesuítas; sobre o teatro de Anchieta, objetos de estudo deste nosso artigo. Há que estudar, ainda, textos que se tornaram, como afirmam Ferreira e Bittar (2007, p. 109), "matriz de uma determinada visão da história da educação brasileira”, caso de A cultura brasileira; afinal, este é um discurso constituído muito mais para nossa época do que tem a ver com o período que descreve. Assim, Azevedo consegue transformar em heróis nacionais, ao mesmo tempo, os jesuítas e a Escola Nova; e, em vilões, a escola tradicional e o Marquês de Pombal. É preciso, então, que esse período seja "redescoberto (idem), retomar assuntos que sumiram da pesquisa sem que se chegasse a alguma conclusão sobre eles" (cf. CARDOSO apud BITTAR, 2006, p. 19), ou que estão cristalizados como verdades inabaláveis.

Neste artigo apresenta-se, primeiramente, a descrição da formação, da fundação e do desenvolvimento inicial da Companhia de Jesus, seguindo os passos de Inácio de Loyola. Traça-se para o leitor um quadro da religiosidade no início do século XVI e suas contradições nesse período de transição do período medieval para a Idade Moderna, de transformações entre o velho e o novo homem, entre o antigo e o novo mundo europeu. Nessas contradições, é que aparece a Companhia de Jesus, uma ordem religiosa que nascia nesse século com vocação missionária, ideais cavalheirescos de salvação da Jerusalém terrestre e celeste e que foi convocada pelo rei Dom João III, para transformar "as Índias" Orientais e Ocidentais e tornar seus habitantes cristãos e católicos.

No Brasil, com a vinda da Companhia de Jesus, em 1549, liderada por Manoel da Nóbrega, revelaram-se os primeiros desafios para os padres jesuítas, como também alguns encontros e desencontros de culturas: a nativa, a do colono, que há muito tempo estava vivendo em meio a esse país selvagem, e a cultura europeia, sobretudo aquela que os padres queriam implantar por aqui. 
Por fim, com José de Anchieta, percorrem-se os caminhos de um jesuíta e de sua obra no Brasil, procurando encontrar como foi a dialética da colonização neste país continente; a cultura que os europeus, homens de sua Majestade, Dom João III, o rei de Portugal e do Papa, Paulo III, queriam formar; e a resistência que a cultura indígena e também a do colono, que criara uma nova forma de vida para viver em meio à mata, impuseram a essa aculturação.

\section{IÑIGO, INÁCIO DE LOYOLA E A FORMAÇÃO DA COMPANHIA DE JESUS}

O basco Iñigo, filho dos senhores de Loyola, mentor, incentivador e primeiro geral da Companhia de Jesus, nasceu em 1491 (LACOUTURE, 1994, p. 11). No ano seguinte, Colombo viajaria para as Índias, navegando pelo Ocidente e encontraria em sua viagem um novo mundo, muito embora visse a Índia diante de seus olhos, incluindo a imaginária existência na futura América do Grande Can.

No novo continente, Colombo seria recebido por homens "selvagens", nus e, decepcionado, não enxergaria nesse homem um ser diferente e de outra cultura: "embora tenham aparência animalesca e andem nus [...] parecem ser bastante razoáveis e de inteligência aguçada [...] desprovidos de qualquer propriedade cultural: caracterizam-se, de certo modo, pela ausência de costumes, ritos e religião" (TODOROV, 2010, p. 48). Segundo Todorov (Ibidem), Colombo não viu o outro, mas, em suas interpretações, enxergaria nesse novo homem, diferente dele, aquilo que lhe diziam seus conhecimentos, suas leituras. Imaginou, por exemplo, que os índios não falavam, porque, na verdade, falavam uma língua que ele não entendia; ou, então, achava os índios "bestas idiotas ao darem tudo por pedaços de barris quebrados" (Ibidem, p. 53), pois não percebia que, na economia indígena das matas, o ouro não tinha maior "valor" que cacos de vidros coloridos. Também via nesse novo mundo semelhanças com suas crenças, tanto religiosas ou míticas. Encontraria "ciclopes, sereias, homens com caudas, amazonas". Ao ver três animais marinhos, enxerga sereias, "mas ele vê que 'as sereias' não são como se disse, belas mulheres; no entanto, em vez de concluir pela inexistência das sereias troca um preconceito por outro e corrige não são tão belas quanto se pensa" (Ibidem, p. 23).

Colombo interpretaria esse novo mundo segundo sua conveniência; afinal, diz Las Casas (apud TODOROV, 2010, p. 36), Cristóvão Colombo é Cristobal, isto é, "Christum Ferens, que quer dizer portador do Cristo" e Colón que quer dizer "repovoador". Teria sido ele, portanto, o eleito pela Providência Divina para abrir as portas desse novo mundo para a entrada de Jesus Cristo e seria o responsável por constituir uma nova Igreja cristã. Afinal, se os habitantes desse lugar são culturalmente virgens, página em branco, então estariam à espera da inscrição espanhola e cristã (Ibidem, p. 49).

A esse trabalho, iniciado por Cristobal Colón, de constituir uma nova Igreja Cristã no Novo Mundo, lançar-se-iam os legionários de Jesus liderados por Inácio, a partir de 1540. O nascimento de Iñigo de Loyola, em 1491, seria um sinal, talvez não das divindades, como pensaria ele, mas dos novos tempos - de Erasmo, de Copérnico, de Maquiavel, de Miguelangelo, de Rabelais, de Thomas More, de Lutero, do rei Henrique VIII, de Calvino e, obviamente, de Colombo e do Novo Mundo.

Iñigo, que mais tarde adotaria o nome Inácio, antes de sair à luta para constituir a nova Igreja Cristã do Novo Mundo, teria que decifrar outros sinais, desta feita emitidos pelas divindades, para fazer suas escolhas. O futuro mentor da Companhia de Jesus tornouse um cavaleiro do rei de Espanha e participaria, em 1521, da luta dos espanhóis, fiéis ao poderoso Carlos V, no cerco dos franceses, súditos de Francisco I, a Pamplona. "Depois de durarem um bom tempo os tiros de artilharia, uma bombarda lhe acertou numa perna e a 
quebrou toda: a bala lhe passou entre as pernas, deixando a outra também bastante ferida." (LOYOLA, 1987, p. 20). Iñigo conta em sua autobiografia que foi operado pelos próprios inimigos, sendo depois levado em uma liteira para sua terra. Lá o operaram novamente, ou melhor, "fez-se de nova carniçaria" (Ibidem).

Recuperado, Iñigo decidiu tornar-se peregrino e ir à cidade Santa para salvá-la das mãos dos turcos. Nesse período e nessa peregrinação, começaria a desenvolver um conjunto de exercícios espirituais, tais quais aqueles que faziam os soldados, mas para formar cristãos prontos para uma guerra espiritual contra as ideias peregrinas que iam surgindo pela Europa, de Lutero, de Calvino, dentre outros. Seriam esses exercícios a arma de Loyola para recrutar seus soldados de Cristo e a base de formação de seus futuros legendários. Exercícios que são inspirados na imitação da vida de Cristo, popular na Europa desse período, e que serão o primeiro método pedagógico jesuítico para o aperfeiçoamento das almas na doutrina cristã.

Iñigo não era padre e aplicava, por intermédio dos exercícios espirituais, penitências e purgações; e, como ele induzia as pessoas a viverem a vida de Cristo, na imaginação, parecendo coisa mística, típica dos perseguidos alumbrados, foi convocado e investigado pelos homens do Santo Ofício, em Alcalá. Decidiu, então, que seria necessário estudar as coisas da fé. De Alcalá, dirigiu-se a Salamanca, cidade universitária. Mas, em 1527, foi preso novamente pelos dominicanos, pelo mesmo motivo. Ficou preso 22 dias com alguns de seus companheiros.

Nesse mesmo ano de 1527, Roma foi invadida e atacada pelas tropas do exército imperial de Carlos V. "Os soldados famintos, não remunerados, lançaram-se numa onda de saques, vandalismo e excesso carnais" (WRIGHT, 2006, p. 23). Mais do que destruição da cidade dos papas, das suntuosas igrejas, das festas, o que ficou simbolizado com esse "inferno" foi que o cisma da Igreja iniciada por Lutero, em Wittenberg, dez anos antes, tornar-se-ia realidade. Afinal a destruição de Roma foi provocada não só por luteranos e outros protestantes, mas também pelos próprios soldados espanhóis, na guerra que estavam travando entre si os reis católicos Carlos V e Francisco I. Por isso mesmo, a Igreja dos papas intensificava a caça aos hereges.

Iñigo foi solto em Salamanca, mas, segundo determinação dos homens do Santo Ofício, devia restringir seus exercícios espirituais àquilo que lhe fosse permitido, não podendo indicar penitências, purgações dos pecados, nem mesmo falar de coisas da fé, já que não era padre. Dirigiu-se a Paris. Quando Iñigo apresentou-se para estudar na universidade, seu diretor, Diogo da Gouveia, o fez prometer que não aplicaria por lá seus exercícios; afinal, havia, com eles, transformado jovens estudantes de famílias abastadas em mendicantes.

$\mathrm{Na}$ universidade, Iñigo recrutaria seus primeiros companheiros de Companhia: Pierre Favre, Francisco Xavier, Diogo Laínez, Afonso Salmeron e Nicolas Alonso, de Palência; por fim, o português Simão Rodrigues de Azevedo, pensionista de Dom João III no colégio Santa Bárbara, em Paris. E, em 1534, em Montmartre, nos arredores de Paris, os sete companheiros pronunciariam, na igrejinha de Nossa Senhora, os votos de ir a Jerusalém para salvá-la das mãos dos turcos e, ao regressar, colocar-se sob a autoridade do Papa, Clemente VII, que seria substituído, naquele mesmo ano, por Paulo III.

No mesmo ano de 1534, o papa Clemente VII convocaria o já renomado pintor Michelangelo para fazer um projeto de pintura do teto da capela Sistina, executado e terminado durante o papado de Paulo III. De um lado, nasceria uma ordem religiosa dos cavaleiros de Jesus, colocando-se sob a autoridade do Papa, com ideais claramente ainda medievais; por outro, a demonstração de um poder suntuoso plantado na modernidade. Foi nesse ano também que Henrique VIII, rei da Inglaterra, rompeu com a Igreja Católica, com 
o papa, e fundou a Igreja Anglicana. Fortes indícios dos tempos e das dificuldades por que passava a Igreja Católica. Ainda no ano de 1534, em São Cristoval da Laguna, Tenerife, nas Ilhas Canárias, no dia de São José, 19 de março, nasceria o outro personagem desta nossa história, o menino José, da família Anchieta.

No pacto de Montmartre, os companheiros decidiram que partiriam para Jerusalém no dia da conversão de São Paulo, 25 de janeiro do ano de 1537, pois antes era preciso preparar-se de corpo e alma para essa obra. Esse ano foi importante para a Companhia, pois, por determinação apostólica, o papa Paulo III decidiu que os índios seriam homens racionais, como nos conta Simão de Vasconcelos, na "Crônica da Companhia de Jesus no Brasil", composta no início do século XVII:

No qual tribunal, depois de vistas as informações de uma, e de outra parte, se determinou com Autoridade Apostólica, como coisa tocante à Fé, que os Índios da América são homens racionais, da mesma espécie, e natureza de todos os outros; capazes de Sacramentos da Santa Igreja e por conseguintes livres por natureza, e senhores de suas ações. (VASCONCELOS, 1977, p. 115).

Esta decisão foi tomada porque, segundo Vasconcelos, "chegaram a ter para si muitos daqueles primeiros povoadores, não só idiotas, mas ainda letrados, que os índios da América não eram verdadeiramente homens racionais nem indivíduos da raça humana" (Ibidem, p. 115), e seria fundamental para a constituição e, sobretudo, para os trabalhos missionários da Companhia de Jesus, principalmente no Brasil, e na sua disputa com os senhores de engenho daqui, já que os índios não poderiam servir como "camelos, cavalos ou um boi", não se poderia "feri-los, maltratá-los, matá-los, sem injúria alguma, restituição, ou pecado" (Ibidem, p. 114). Eles poderiam receber sacramentos, e, portanto, ser convertidos.

No entanto, os índios continuariam a ser escravizados por colonos espanhóis, portugueses, franceses, mas isso era contra a lei, e esses apresadores teriam em seu encalço, após a determinação do papa Paulo III, os homens do governo e, principalmente, os padres da Companhia de Jesus. Seriam, por exemplo, denunciados no palco do teatro de Anchieta, em Vila de Vitória, como aliados de Satanás. Claro também que os índios eram escravizados pelos homens do governo, nos aldeamentos, junto aos padres da Companhia, mas em guerras "justas" (cf. VAINFAS, 1995).

No ano de 1537, os dez companheiros reunidos em Veneza iriam até Roma pedir permissão e bênção ao papa para a viagem a Jerusalém. O mestre Iñigo que, a partir desse período passaria a assinar também Inácio, certamente latinizando seu nome, e não para prestar uma homenagem ao Santo descrito na Legenda Áurea, como pode parecer (MONUMENTA IGNACIANA, 1909), foi chamado ao convento de Monte Castelo, em Roma, pelo embaixador de Carlos V na Santa Sé, Don Pedro de Ortiz, a fim de aplicar-lhe os exercícios. Não pôde ir, portanto, para a audiência com Paulo III. Foram seus companheiros, que voltaram com a bênção e com dinheiro para a viagem a Jerusalém. Infelizmente, a cidade Santa estava com suas portas fechadas pelos turcos, que haviam rompido relações com os venezianos. Assim, a peregrinação para lá ficou impossibilitada, dirigindo-se, então, todos para Roma, para colocarem-se à disposição da Santa Sé.

No período em que aguardavam para serem recebidos pelo Papa, de 1538 a 1540, aconteceu uma importante troca de cartas: de Diogo de Gouveia, o reitor do colégio de Santa Bárbara, para Dom João III, rei de Portugal; de Pedro Favre para Gouveia; e de Dom João III para Dom Pedro Mascarenhas, embaixador de Portugal junto à Santa Sé, em Roma. Neste momento da narrativa, pede-se ao leitor que fique atento à leitura dessas 
cartas, pois deram um novo rumo aos objetivos missionários e de luta da nova ordem religiosa, que sequer havia sido instituída oficialmente.

Diego da Gouveia, em carta de 16 de fevereiro de 1538, sugeriu ao rei Dom João III que entrasse em contato com seus ex-estudantes do colégio de Santa Bárbara, principalmente os mestres Iñigo, Pedro Favre e o português Simão Rodrigues, para irem à Índia, "pois que são homens próprios para essa obra, de converter toda a Índia" (LEITE, 1954a, p. 95,). Diz ao rei que os indianos seriam bem mais fáceis de converter do que os mouros, tarefa à qual se tinham proposto os companheiros de Jesus. Aqui há um primeiro indício das mudanças no rumo da Companhia de Jesus. Se, em 1534, em Montemartre, os primeiros jesuítas organizaram-se em torno do ideal cavalheiresco de salvar Jerusalém das mãos dos turcos e de colocar-se à disposição do papa, agora, com a movimentação política do influente reitor da Universidade de Paris, os ventos passaram a soprar a favor dos indianos, que seriam mais fáceis de converter do que os mouros, e concretizar-se-ia, assim, a expansão política e de consciências nas colônias do reino português.

Gouveia enviou uma carta ${ }^{1}$ a seu ex-estudante, Pedro Favre, relatando o seu pedido feito ao rei de Portugal. Pedro Favre lhe respondeu, em carta de 23 de novembro de 1538, que ele e seus companheiros gostariam muito de trabalhar "com os vossos Indianos", mas que havia um impedimento:

se puseram à disposição do Sumo Pontífice e que é ele quem decide se devem partir ou não, mas que há algum tempo não faltou quem procurasse conseguir que ele nos mandasse para os índios, que os espanhóis vão sujeitando ao Imperador, para conseguir falaram primeiro a um Bispo espanhol e ao Embaixador imperial, mas estes notaram que a vontade do Sumo Pontífice não era que saíssemos daqui...(Ibidem, p. 100).

Parece uma forma delicada de dizer "não, não queremos ir trabalhar com vossos indianos". O projeto inicial de Loyola e dos primeiros jesuítas era o resgate da cristandade e da Igreja Católica, em crise intensa, no continente europeu. É bom lembrar que Pedro Favre havia sido enviado para a Alemanha e Diogo Laínez se tornara interlocutor do Papa no Conselho Tridentino.

D. João III escreveu, então, em 4 de agosto de 1539, para seu embaixador em Roma, D. Pedro Mascarenhas, para que ele dissesse ao papa que sua intenção, como todos sabiam, era enviar para todas as suas conquistas homens letrados e de bem, para a maior glória de Nosso Senhor. Que ele fora informado por carta, pelo Mestre Gouveia, que haviam partido de Paris para Roma clérigos de bem e letrados, dispostos a converter infiéis. Que esses clérigos haviam dito a Gouveia que estavam sob o mando do Papa. Para ele, então, interceder junto ao Sumo Pontífice, a fim de enviar esses homens para Portugal, para que eles pudessem partir para as terras conquistadas.

D. Pedro Mascarenhas respondeu ao rei de Portugal, em carta de 10 de março de 1540, dizendo que havia pedido aos clérigos e que eles responderam "que não tinham querer, porque se colocaram à disposição do Papa para irem onde ele os mandasse, ainda que fosse mais longe que a Índia" (Ibidem, p. 106). Ele foi pedir, então, ao Papa dois pares desses clérigos e depois mais. O Papa lhe disse que os clérigos eram homens bons, letrados, virtuosos e que estavam fazendo grande proveito na conversão dos que tinham se afastado da fé. Que tinha entendido as boas intenções de D. João, mas que "para jornada tão larga e perigosa havia necessidade que eles a tomassem voluntária: por isso que os rogasse eu, e que depois lhos mandaria" (Ibidem, p. 106). O embaixador informou ainda que tinha havido pouco trabalho na conversa com os companheiros de Jesus, pois os 
clérigos decidiram ir para a Índia com grande contentamento. Mas apenas dois deles, pois os outros seis estavam em outras missões, pela Europa.

Foram destacados para a viagem Simão Rodrigues, português, e o castelhano Nicolau Alfonso de Bobadilha, trocado por Francisco Xavier, porque havia se ferido (LACOUTURE, 1994, p. 110). Foi com eles também um jovem italiano, Paulo de Camerino, que iria com Xavier para as Índias (LEITE, 1954a, p. 107). Simão Rodrigues estava doente, como relata ainda nessa carta Dom Mascarenhas: havia chegado agora de Sena, onde estivera reformando um mosteiro de mulheres a mandado do Papa e de lá havia voltado "quartanayro. E por esta causa de sua indisposição, de que Deus seja louvado, já está melhor" (Ibidem, p. 107), mas, mesmo assim, retirou-se à quinta da Palma, de D. Mascarenhas, em Portugal, para nela convalescer.

Em vinte sete de setembro de 1540, os peregrinos mendicantes seriam recebidos em audiência por Paulo III e veriam aprovadas (também pelo conselho de cardeais), na bula Regimini Militantes Ecclesiae, a instituição e a primeira constituição da Companhia de Jesus. Instituída oficialmente a Ordem de Jesus, em 1541, Inácio de Loyola seria eleito o primeiro geral da Companhia, iniciando em 1547 a composição de sua Constituição, finalizada em 1552. Mas, no ano de 1556, ano da morte de Inácio de Loyola, este fez revisões e alterações nas regras da Ordem.

E assim, no mesmo ano de aprovação institucional da Companhia de Jesus, em Lisboa, Francisco Xavier e Simão Rodrigues eram hóspedes de sua Majestade D. João III. Esperavam o momento certo para partir às Índias Ocidentais. Preparavam-se mentalmente, pois na bagagem não levariam mais que um crucifixo, alguns livros, entre eles, o livro de horas e o manual de exercícios espirituais. Francisco Xavier deixaria para trás Lisboa, este mundo misturado entre o antigo: os autos de fé em que figuram todas as práticas medievais de intolerância religiosa, e o novo: os novos conhecimentos, as novas ideias que circulavam trazidas pelas naus, pelos professores das escolas, colégios portugueses; e com Paulo Camerino, no ano de 1541, seguiriam viagem para a Índia. Por fim, Simão Rodrigues ficou em Lisboa e tornar-se-ia o primeiro provincial da Companhia em Portugal.

Nesta releitura e "redescoberta" da formação da Companhia de Jesus e sua inserção no Novo Mundo, chama-se a atenção do leitor para duas questões essenciais, singulares, mas nodais (FOUCAULT, 2002, p. 30, passim). A primeira questão relaciona-se aos exercícios espirituais que foram desenvolvidos por Inácio de Loyola e que se tornariam arma importante para a formação moral, religiosa cristã e católica, assim como para a sedução dos membros da Companhia e também dos fiéis. Exercícios que prostram o exercitante como ator da Vida de Cristo (cf. HERNANDES, 2007). Essa arma poderosa seduzia tanto mendicantes quanto nobres, como o já citado embaixador de Carlos $\mathrm{V}$ junto à Santa Sé, Don Pedro de Ortiz; ou Dona Cataria D’Áustria, esposa de Dom João III, rei de Portugal (HERNANDES, 2008 b). Instrumento poderoso que abriu caminhos junto à arraia miúda para a popularização da Companhia de Jesus, bem como entre pessoas importantes e influentes.

A outra questão é a importante participação de Diogo de Gouveia, reitor do colégio de Santa Bárbara e da Universidade de Paris, em que estudaram Loyola e seus primeiros companheiros. Anti-humanista e anti-Erasmo, é ele, com sua forte influência, quem sugere ao rei Dom João III enviar clérigos para as colônias, a fim de dar uma formação moral e religiosa por lá. Ele é quem estabelece contato entre o Rei de Portugal e os membros da Companhia.

A esses nós estão amarrados a expansão da Companhia de Jesus, em Portugal e em suas colônias, e as bases pedagógicas para a evangelização, antes da Constituição e da Razão de Estudos - Ratio Studiorum. Para vir ao Brasil, a Colônia Continente de Portugal, 
é destacado como líder o soldado de Cristo, forjado pelos exercícios espirituais, Manoel da Nóbrega, e é com ele que se segue viagem neste texto a partir de agora.

\section{COM MANOEL DA NÓBREGA, A COMPANHIA DE JESUS VEM AO BRASIL}

Nos tempos em que Simão Rodrigues e Francisco Xavier circulavam por Lisboa e Coimbra, preparando-se para a viagem às Índias ou para organizar a Companhia em Portugal, também por lá estaria Manoel da Nóbrega, preparando-se, sem o saber, para fazer parte da história da Companhia, de sua missão e, principalmente, de sua construção no Brasil. Nóbrega era filho do desembargador Balthazar da Nóbrega, estimado d’El Rei Dom João III, e ele próprio recebia do rei moradia e favor para seus estudos, segundo o jesuíta do século XVII e um dos primeiros biógrafos de Manoel da Nóbrega, Antonio Franco (NOBREGA, 1988). Nóbrega era gago e teve dificuldades para conseguir lugar no Mosteiro de Santa Cruz, como professor, assim como na Universidade de Coimbra. Dessa forma, decidiu entrar para a Companhia de Jesus, em 1544, quando já era padre. Nóbrega "foi encomendado pela Obediência o ofício de tratar com o próximo em pregações, confissões, visitar cárceres e hospitais e acudir outras necessidades espirituais e corporais de pessoas particulares" (Ibidem, p. 23). Mas, a estima d'el rei e o parentesco com o Desembargador talvez o tenham ajudado a ser o primeiro jesuíta a vir para o Brasil.

Quando, em 1548, o rei Dom João III resolveu enviar os homens da Companhia de Jesus para o Brasil, Simão Rodrigues ofereceu-se para ir: "quero ser o primeiro no Brasil, pois não mereci ser o segundo na Índia" (RODRIGUES apud LEITE, 2000a, v. 1, p. 17). Rodrigues comunicou Loyola sobre a decisão de Dom João III e a sua própria, o que parece ter causado, segundo Leite, certo desconforto em Loyola e nos companheiros que estavam em Roma, que não tiveram outra alternativa, a não ser aguardar os acontecimentos. Por fim, Rodrigues não poderia ir, já que Padre Santa Cruz, que o substituiria em Portugal, morreu naquele mesmo ano, e ele, ao que tudo indica, teria percebido que não poderia sair da Europa naquele momento. O escolhido para substituí-lo seria o jovem de 32 anos, Manoel da Nóbrega.

No ano de 1549, a primeiro de fevereiro, partiu de Lisboa a frota do primeiro governador do Brasil, Tomé de Souza, levando consigo alguns padres e irmãos da Companhia. Nóbrega não chegou a tempo da partida em Lisboa, embarcou mais tarde na nau do provedor-mor, Antonio Cardoso de Barros, que alcançou a frota e pôde, então, embarcar na nau capitânia, juntamente com seus companheiros a quem liderava: os padres Leonardo Nunes, João Aspicuelta Navarro, Antonio Pires e com os Irmãos Vicente Rodrigues e Diogo Jácome. Chegaram à Bahia após oito semanas no mar, em 29 de março de 1549.

Desembarcaram na povoação de Pereira, do primeiro donatário da Bahia, Francisco Pereira Coutinho, chamada depois de Vila Velha, por oposição à vila nova que se construiu no Recôncavo. A futura cidade de Salvador não contava com mais de cinquenta portugueses, que deveriam ser o Caramuru e seus parentes, segundo Nóbrega, e "que nos receberam com grande alegria e achamos uma maneira de igreja, junto da qual logo nos aposentamos os Padres e irmãos em umas casas a par delas" (NÓBREGA, 1988, p. 71). Em 31 de março de 1549, domingo, Nóbrega celebraria a primeira missa por jesuítas no Brasil. O gentio da terra, depois de feitas as pazes, ajudaram a encontrar o lugar e a construir a cidade do Salvador. Juntamente com a cidade, os padres da Companhia construíram a primeira igreja dessa ordem no Brasil, a de Nossa Senhora da Ajuda, provavelmente também a primeira igreja de Salvador. 
Nóbrega, em sua chegada, relatou em carta que os habitantes primitivos do Brasil "são tão brutos que nem vocábulos têm ou tem mui poucos vocábulos para lhes poder bem declarar nossa fé" (NOBREGA apud ANCHIETA, 1990, p. 140), não muito diferente do que pensara o navegador Cristóvão Colombo mais de cinquenta anos antes.

Os padres da Companhia foram viver em uma aldeia de índios, tentaram ensinar a doutrina cristã, com intérpretes que eram "bons línguas", isto é, que falavam bem a língua dos índios e opuseram-se violentamente contra os costumes nativos, principalmente a antropofagia (NÓBREGA, 1988, p. 73). Causaram, com isso, intensa revolta dos índios. Tiveram, então, que se retirar, tendo o governador que intervir com toda a sua força e dar ordem para que os padres "ocupassem umas casas de barro, no lugar onde haviam de permanecer, depois, no seu apostolado por mais de dois séculos" (LEITE, 2000, p. 25).

Parece que Nóbrega e seus companheiros esqueceram-se dos preceitos da Constituição da Companhia, tal qual um cadáver. No lugar determinado pelo governador Tomé de Souza, os jesuítas começaram a construir o colégio (inicialmente para meninos órfãos) e a igreja da Companhia de Jesus, que por muito tempo foi de palha e feita pelos próprios padres. Somente com Mem de Sá, o terceiro governador geral do Brasil, construíram-se a Igreja e o colégio com pedra e cal. Iniciada a construção, em 1561, com o esforço do próprio governador, foi fundada em 1564. Nessa igreja, ainda não terminada, Anchieta teria exercitado ministérios pela primeira vez, em 1566.

Depois daquele episódio quase trágico, os jesuítas do Brasil perceberiam que, para transformar a cultura de um povo, era preciso antes inserir-se nessa cultura, conhecê-la de dentro. Os homens primitivos do Brasil viviam na selva, lugar e realidade material muito diferente daqueles nos quais viviam os homens da Europa. Os europeus que para aqui vieram, os colonos portugueses, tiveram que aprender com os nativos como viver nesse novo ambiente, como nos conta Navarro, em carta de 1550 - "vos informei do fruto que se esperava nestas terras não só com os gentios, mas ainda com os cristãos que aqui viviam em conformidade com eles e talvez piores costumes" (NAVARRO et al., 1988, p. 75). Muito mais que ensinar a cultura, a religião europeia, era necessário, até por uma questão de sobrevivência, aprender a cultura indígena. Afinal, eram os índios que sabiam viver na selva entre cobras e jacarés, morcegos e jaguares. Era fundamental aprender a língua dos índios, "trabalhamos de saber a língua e o padre Navarro leva vantagem a todos" (NÓBREGA, 1988, p. 73). Assim, os primeiros trabalhos da Companhia no Brasil teriam sido recrutar colonos portugueses, bons línguas, isto é, que falavam a língua geral dos brasis, o tupi, para mediar o contato dos jesuítas que aqui estavam e, também, para ensinar aos padres que estavam chegando o domínio dessa língua. Segundo Navarro, referindo-se a um grupo de "disciplinantes" que queriam ser religiosos: "desejam muitos ser religiosos e alguns foram admitidos na Companhia como peritos na língua brasílica e outros recusados por não serem idôneos" (NAVARRO et al., 1988, p. 78). Nóbrega tinha como missão a expansão da Companhia de Jesus e, para recrutar guerreiros, sobretudo aqueles que eram bons línguas e eram conhecidos dos índios, abria mão de regras e leis da Companhia, às vezes até da própria Igreja Católica, o que lhe custou aborrecimentos e, talvez, o cargo de Provincial. Mas, na realidade das matas brasileiras, ou se enfrentavam os problemas, como fez Nóbrega, ou a Companhia de Jesus não teria conquistado tantas almas para o reino de Deus.

Aprendida a língua, entrando na cultura, perceberam os jesuítas a importância que tinha para os índios, por mais horror que isso pudesse causar a todos, comer carne humana. Conta Navarro (NAVARRO et al., 1988, p. 77) que, indo às aldeias e pregando, alguns índios, maravilhados, pediam para serem batizados, mas ele, por dois motivos, não o fazia: 
primeiro porque não tinham rei a quem obedecer nem moradia certa, o que fazia que seguissem seus feiticeiros; a outra causa é preciso deixar Navarro dizer:

A outra razão, não menos eficaz, de diferir o Batismo é que muito arraigado está neles o uso de comer carne humana, de sorte que, quando estão em artigo de morte, soem pedi-la, dizendo que outra consolação não levam senão esta, da vingança de seus inimigos, e quando não lha acham dar, dizem que se vão o mais desconsolados deste mundo. Gasto grande parte do tempo em repreender esse vício; replicam alguns que comem-na somente as velhas; outros dizem que seus antepassados comeram e que eles devem comer carne humana. Dizem outros que é o modo usual de vingarem-se, e que os contrários praticam o mesmo a respeito deles e que eu não deveria arrancar-lhes este seu alimento (NAVARRO et al., 1988, p. 77)

Para Nóbrega (1988), havia pelo menos duas outras dificuldades para transformar a cultura dos nativos, torná-los cristãos, católicos: uma delas era o péssimo exemplo que davam os próprios cristãos que aqui viviam, os colonos; e a outra eram os feiticeiros. Conta o padre que, certa vez, quando batizaram muitos índios, incluindo alguns principais, estes passaram mal do "ventre" e os feiticeiros diziam que isso era ocasionado pela água do batismo. Resolvido o problema, Nóbrega procurou o principal "feiticeiro, o maior da terra ao qual procuravam todos para os curar em suas enfermidades" e perguntou a ele qual era a comunicação que ele tinha com Deus que criou o céu e a terra e que reina no céu, ou se tinha comunicação com o Demônio que reina no inferno. O feiticeiro lhe respondeu que "ele era Deus e tinha nascido Deus e apresentou-me um a quem havia dado a saúde, e que aquele Deus dos céus era seu amigo e lhe aparecia frequentes vezes nas nuvens, nos trovões e raios" (Ibidem, p. 95). Evidentemente, Nóbrega utilizava o vocábulo Tupã para significar Deus. Por essas e outras razões, Nóbrega chegou a duvidar de que os nativos tivessem condições de aprender a palavra de Deus, e, muito provavelmente, os índios também duvidaram se os padres teriam condições de aprender sua cultura e sua religião, que não tinha Deus nem diabo (cf. HERNANDES, 2008a).

Em 1553, o Brasil tornou-se uma Província da Companhia de Jesus. Manoel da Nóbrega foi indicado como seu primeiro provincial, pelas letras do próprio Loyola, em carta de 9 de julho de 1553:

Nós, portanto, da vossa piedade e prudência, que está em Cristo Jesus, confiando muito no mesmo Jesus, vos criamos e constituímos, com toda a autoridade, que a Sé Apostólica nos concedeu e as Constituições da nossa Companhia nos conferem, e em virtude da santa obediência, Prepósito Provincial de todos os Nossos (LEITE, 1954a, v. 1., p. 508).

Como provincial, Nóbrega levou adiante o ideal missionário jesuítico de arrebanhar homens para Deus. Mesmo antes de tornar-se provincial, em 1551, procurava sair da costa brasileira e adentrar a floresta. Com o cargo de provincial, esse ideal se fortaleceria. A construção — não por acaso - de uma casa e um colégio em Piratininga, próximo das terras dos carijós, em que os castelhanos tinham submetido mais de 50 mil gentios, o levaria a outro ideal: evangelizar a "gentilidade guaranítica" (AGUILAR, 2002, p. 116).

Nóbrega teria decidido conquistar a "cidade do Paraguai", no caminho de São Vicente e de Piratininga, mas Tomé de Souza, mesmo assegurando que as terras do Rio da Prata pertenciam à Coroa portuguesa, desaconselhou-o (proibiu-o). Nóbrega não descansaria em seu intento e enviaria uma carta, em 1555, para o Padre Inácio de Loyola, a 
fim de relatar a necessidade que aquelas terras tinham de padres da Companhia: "Eu sou importunado cada dia assim dos espanhóis por cartas que me mandam, como dos mesmos índios, que vêem de muito longe com grandes perigos, buscar-nos". Nóbrega disse não ter ainda enviado alguém, por não ter gente suficiente, mas estava esperando pelo Padre Luiz da Grã, ao mesmo tempo que aguardava o conselho do principal da Companhia, para ir, ele mesmo, para lá (LEITE, 1954b, v. 2, p. 58). O provincial da Companhia no Brasil queria levar a missão jesuítica para o rio da Prata, onde pretendia fazer um ninho da Companhia, já que São Vicente ia se despovoando e os gentios eram nômades. Em 1557, percebeu que aquele com quem contava para essa empreitada, Luiz da Grã, o segundo da Companhia no Brasil, não era favorável a essa tarefa:

vivendo eu com este desejo o deixei por pôr obra, por não ter quem mandar e algumas vezes estive determinado de eu mesmo lá ir a saber o que se poderia fazer; nisto chegou o Padre Luiz da Grã o qual desejei muito que fosse, mas porque o achei de opinião contrária adquiess concilío ejus. E tive meu espírito suspeitoso (NÓBREGA, 1988, p. 175).

Teve receio, também, de "que Sua Alteza poderia ter disto algum desgosto, e esta foi a principal razão que isto estorvou" (Ibidem).

Nóbrega foi demitido do cargo de Provincial do Brasil, em 1559, por meio de carta que ele mesmo levou para aquele que seria o segundo Provincial, padre Luiz da Grã. Quem o demitiu foi o provincial da Companhia em Portugal, padre Miguel de Torres, que, ao fazer isso, tarefa que pertencia ao geral da companhia, Diogo Laínez, desobedeceu as regras da própria Companhia, já que, apesar de a Província do Brasil ter comunicação e muita inteligência com Portugal, "está todavia imediatamente debaixo do Prepósito Geral em Roma” (LEITE, 1954a, v. 1, p. 510). Dr. Torres teve que explicar-se e escreveu ao Geral da Companhia, Padre Laines, que Nóbrega estava muito doente e estava causando muitos conflitos no Brasil com sua política.

Las razones son que en La Bahia estan todos muy escandalizados Del Padre Manuel da Nóbrega, ansi las personas ecclesiásticas como seculares. Parece que no puede facilmente moderar el zelo ni acomodarse a las complesiones de los hombres... (Ibidem).

Leite (2000a, v. 1, 465, passim) assegura que Nóbrega foi demitido porque era desobediente às ordens da Companhia e, para conseguir o que queria, não observava as normas. Luiz da Grã, aparentemente, era mais obediente aos ditames da Companhia e, segundo Leite, menos influente, tanto com os gerais da ordem quanto com o governador do Brasil na época, Mem de Sá (Ibidem). A principal divergência era que Nóbrega via como fundamental cuidar do temporal (do político e até do militar na Colônia) e não só do espiritual (LEITE, 2000a, v. 2, p. 409, passim). Em carta de 1552 a Simão Rodrigues (NÓBREGA, 1988, p. 138), faz um relato da infraestrutura material que estava realizando para criar os meninos gentios, habituados a mil anos em costumes perversos:

trabalhamos por dar princípio a casas, que fiquem para enquanto durarem o mundo... casa de meninos nestas partes são muito necessárias e não se pode ter sem bens temporais e de maneira que esta casa está fundada, e sendo assim há de haver estes e outros escândalos.

Apesar de reconhecer que esta decisão de ter bens temporais contrariava algumas regras da Companhia e causava murmúrios e rumores ${ }^{2}$, Nóbrega seguiria com sua 
determinação de construir a Companhia de Jesus também temporalmente, o que divergia de alguns membros da própria Companhia.

Luiz da Grã, em carta para Inácio de Loyola, em 1556, questionou as atitudes de Nóbrega. Perguntou a ele se a esmola que El Rei dava para a casa dos meninos de São Paulo de "Piratinin" não era como soldo, pois nos livros dos almoxarifes constava: "Hulano de La Compañia tiene vendido tanto de su ordenado" e perguntava se não seria melhor que recebessem algo D'El Rei para o Colégio para abrigar "los Hermanos". Questionou o trabalho do ferreiro, irmão Noguera, que fazia obras para os índios em troca de alimentos: "é repugnante", diz ele, além do que "es el ia viejo enfermo". Acrescentou que não poderia a casa ter vacas leiteiras, porque não poderia, segundo a Constituição, no que tange às obrigações do rector, receber gente de fora, nem "los ñinos" (LEITE, 1954a, v. 1, p. 290)

Mas, mesmo com murmúrios e escândalos e não sendo mais provincial, Nóbrega continuou com seu trabalho de construção temporal e espiritual da Companhia. "Com tal determinação, lentamente foi se construindo toda a infraestrutura econômica de sustentação da ação evangelizadora da Companhia de Jesus no Brasil colonial." (FERREIRA JÚNIOR; BITTAR, 2007, p. 40). Ação evangelizadora que encontraria em José de Anchieta, de quem se passa a falar agora, o mesmo empenho e a mesma determinação.

\section{O CANARINO JOSÉ DE ANCHIETA VEM AO BRASIL}

Anchieta nasceu em 1534 nas ilhas Canárias, filho de Juan de Anchieta e de Mencia Diaz de Llarena. Na ilha, estudou no colégio dos dominicanos, onde teria aprendido latim, pois, quando foi para Coimbra, em 1548, para estudar no colégio Real, entrou para as últimas classes dessa língua. Em 1551, momento difícil por que passava o colégio e a cidade de Coimbra, com a perseguição dos homens do Santo Ofício, Anchieta entrou para a Companhia de Jesus. Após ser aceito na Companhia, o noviço era obrigado a fazer votos de obediência, pobreza, castidade segundo os cânones de 1540, aprovados pelo Papa Paulo III, confirmados pelo papa Júlio III, em 1550. Anchieta teve, além disso, e com certeza, que praticar os exercícios espirituais que se incluíam nesses cânones. A Companhia de Jesus "foi instituída principalmente para o aperfeiçoamento das almas na vida e na doutrina cristã, e para a propagação da fé, por meio de pregações públicas, do ministério da palavra de Deus, dos Exercícios Espirituais." (CONSTITUIÇÕES DA COMPANHIA DE JESUS, 1997, p. 22).

Da prática dos exercícios espirituais talvez tenha adquirido a corcós, uma doença nas costas, que fez antecipar sua partida para o Novo Mundo, a fim de curar-se. Considerase essa tese, pois o momento em que Anchieta entrou para Companhia de Jesus, em Coimbra, estava por lá, como principal, Simão Rodrigues.

Rodrigues se dirigia a Portugal em um tempo que eles estavam completamente absorvidos pelas prédicas ambulantes, impregnadas de patetismo e pelas mortificações [...] No colégio dirigido por ele em Coimbra, engendrara-se uma estranha atmosfera de fanatismo, dado que ali os estudantes se entregavam à prática das formas mais barrocas, que imaginar de auto-mortificações. (MILLER, 1935, p. 96)

Doente e com a intenção de curar-se por aqui, Anchieta veio para o Brasil em 1553. A armada que traria José de Anchieta partiu de Lisboa a 8 de maio, chegando ao Brasil em 13 de julho. No Brasil, ficou na Bahia até outubro de 1553, lugar em que, tão logo chegou, 
iniciou a estudar o tupi, a língua mais usada da costa brasileira. Afinal, o idioma tupi foi mais praticado que o português, e em toda a costa brasileira predominou o nheengatu, que quer dizer "o esforço de falar o tupi com boca de português" (RIBEIRO apud FERREIRA JÚNIOR; BITTAR, 2004, p. 181) Os jesuítas, desde a sua chegada, transformaram o tupi em uma língua geral, pois era fundamental aprender a língua dos dominados para melhor catequizar (Ibidem). Segundo Hansen (2005), suplementaram o nheengatu, o tupi, a língua geral, para torná-la conveniente à sua "política expansionista".

Em outubro, Anchieta embarcaria com o padre Leonardo Nunes, que viera com o padre Manoel da Nóbrega, em 1549, para São Vicente, lugar em que a amizade dos portugueses com os nativos já se fazia intensa e onde os padres jesuítas estavam tendo mais sucesso. E, também, lugar mais próximo aos castelhanos do Rio da Prata, da cidade do Paraguay. A caravela em que viajavam foi açoitada por uma terrível tempestade em Abrolhos, naufragaram, mas conseguiram salvar-se, chegando ao Espírito Santo para reparar os estragos. Foram ajudados pelos índios, tendo seguido viagem e chegado a São Vicente em 24 de dezembro de 1553.

De São Vicente, Anchieta seguiria, com o padre Miguel Paiva e com mais doze ou treze irmãos jesuítas, para a aldeia nova de Piratininga e participaria da construção de uma casa e de uma igreja pequena e muito fria, como a descreveu Anchieta. A vila recebeu o nome de São Paulo, por ter sido inaugurada com uma missa em 25 de janeiro de 1554, dia em que se deu a conversão desse santo ao cristianismo. Na construção da casa e da igreja, foram ajudados pelos índios do lugar, cujos filhos iriam ser catequizados. Iniciou imediatamente o ensino de latim para os irmãos jesuítas que, na sua maioria, foram recrutados pelo Padre Leonardo Nunes para a Companhia de Jesus no Brasil. Homens que viviam aqui, antes da chegada dos jesuítas, alguns deles foram recrutados por serem "bons línguas", como é o caso dos alunos de latim de Anchieta, que acabaram morrendo entre os índios e tornando-se mártires, Pero Corrêa e João de Souza. Com certeza, houve entre os irmãos, o grande latinista e os "bons línguas", uma troca muito interessante da qual resultou, já em 1556, feita aos moldes da gramática latina, pelo irmão Anchieta, uma gramática da língua mais usada na costa do Brasil, que se espalhou rapidamente por todos os colégios da Companhia e, em 1595, contava com uma primeira edição em Portugal. Segundo o Padre João de Melo, em 1560, o Padre Luís da Grã, "ordenou em casa que houvesse uma hora de lição de língua brasílica, que cá chamamos grego, e ele é o mestre dela, por saber entender e explicar suas regras melhor que todos, posto que sejam mui boas línguas" (ANCHIETA, 1990, p. 141). De acordo com Ferreira Júnior e Bittar (2004), citando Serafim Leite, os estudantes chamavam o tupi de grego, com certa ironia, pois, no curso de humanidades no Brasil, houve mudança no currículo em relação aos colégios europeus e, no lugar de os alunos aprenderem o grego, aprendiam o tupi.

Diferentemente de Colombo, que acreditou que os índios não falavam, pois falavam uma língua que ele não entendia; ou de Nóbrega, em seu primeiro contato, que achou serem os índios uns brutos e não terem vocábulos para entenderem a mensagem de Cristo, agora, os jesuítas não só aprendiam a língua dos índios como a comparavam, mesmo com ironia, com o grego. Além disso, desenvolviam uma gramática da língua mais usada na costa do Brasil para ensinar aos estudantes dos colégios e àqueles que vinham para trabalhar na conversão dos índios ao cristianismo. É que, manejando a língua, entrava-se mais facilmente no que poder-se-ia chamar de ideologia indígena: seus mitos, religião, sua organização social, para então tentar destruí-la. Somente então seria possível "ensinar os bons e criticar os maus costumes" - segundo evidentemente uma visão cristã -, valendo-se de festas religiosas e encenações teatrais. "Para 'crescer e expandir-se', os valores ocidentais precisavam ser transmitidos de forma que pudessem ser aceitos e, para tal, os 
jesuítas recorreram às práticas mais condizentes com a cultura daqueles que eram seu objeto de conversão." (FERREIRA JÚNIOR; BITTAR, 2004, p. 184).

Há uma relação dialética - de certa forma um confronto - entre a construção histórica e material da vida nas matas, expressa pelo tupi, a língua dos índios, e aquilo que é próprio de uma religião e de uma moral, vindo de outro clima e lugar (HOLANDA, 1963), que os padres queriam ensinar aos índios. Desse confronto nasceu a língua geral, o nheengatu, que é a língua tupi, mas com vocábulos "descontextualizados", segundo o interesse dos padres, para fazer a correção na alma dos índios (HANSEN, 2005, p. 19). Não poderia deixar de ser assim, pois não se tratava de criar uma nova língua, a qual, como o português, dificultaria mais ainda o aprendizado dos índios para as coisas que realmente importavam para os padres ensinar, e, sim, de fazer uma síntese entre o tupi e os conceitos cristãos.

No entanto, é importante dizer, essa síntese não resultaria no que queriam os padres. No teatro de Anchieta, na língua dos índios, Tupã não se transformou em Deus, nem o anhangá em diabo, mas Tupã continuou com seu significado de trovão, nuvem e raio, chuvas e tempestades, sendo misturado à entidade celeste cristã, Deus. Do mesmo modo, o diabo manteve suas significações de espírito malfazejo das matas, recebendo alguns contornos do diabo cristão. Pior, para desalento dos padres: essa síntese linguística parece ter provocado certo hibridismo cultural (VAINFAS, 1995), um sincretismo estranho (BOSI, 1992) ou uma mestiçagem cultural (TODOROV, 2010), e Tupã parece ter-se tornado, para os índios, os mestiços e até, para alguns portugueses, um homem santo, um pajé, conforme conta Vainfas (Idem) sobre a santidade jaguaribe.

Anchieta foi um dos principais responsáveis por esse hibridismo cultural, pois penetrou fundo na cultura indígena e, assim, soube colocar em seu teatro personagens que a representavam, para poder criticá-la de dentro. No Auto da pregação universal, como no Auto de São Lourenço, as principais personagens do mal, Aimbirê e Guaixará, foram inspiradas em verdadeiros chefes tamoios. De Aimbirê, tem-se inclusive uma descrição feita por Anchieta, quando o encontrou em Iperoig. É interessante ouvir a descrição em sua própria fala:

[...]chegando pois aquele principal (Aimbirê) com suas dez canoas veio logo falar-nos com danado ânimo, o qual era homem alto, seco, e de catadura triste e carregada e de quem tínhamos sabido ser mui cruel. Este, pois entrou com muitos dos seus com um arco e flechas na mão, vestido numa camisa, e assentado em uma rede começou a tratar das pazes e a tudo o que lhe dizíamos se mostrava incrédulo e duro, trazendo à memória quantos males lhe haviam feito os nossos, e como a ele mesmo haviam já prendido em outro tempo com pretexto de pazes, mas que ele por sua valentia, com uns ferros nos pés, saltara do navio e havia escapado de suas mãos, e com isto arregaçava os braços e bulia com as flechas contando suas valentias (ANCHIETA, 1988a, p. 216).

Anchieta exploraria a figura desse valente personagem da vida social indígena por meio da sua personagem teatral, derrotando-o em cena, não em luta valente, mas ridicularizando aquilo que ele representava na organização social dos tupinambás. Aimbirê, nos autos da Pregação universal e de São Lourenço apresentar-se-ia assim para a plateia: 


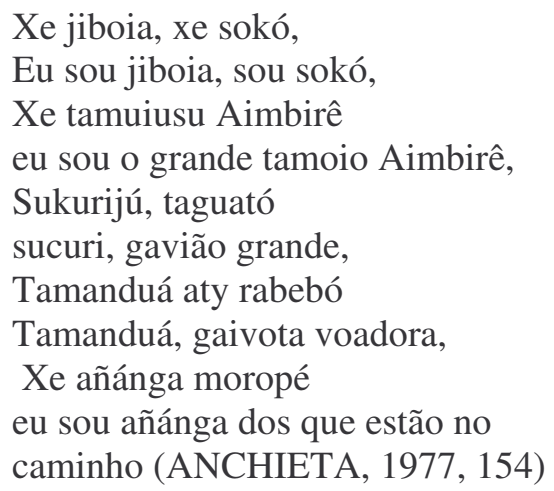

Ele é o grande tamoio Aimbirê, mas é também um añánga dos que estão pelo caminho. Ora, ser um añánga estava reservado, segundo a religião dos tupinambás, àqueles que foram covardes, não vingaram seus inimigos e não foram sacrificados por eles (METRAUX, [s.d.]; FERNANDES, 1970). Essa personagem foi caracterizada não por aquilo que os índios mais prezavam nos seus morubixabas, a luta e a valentia, que, parece, eram as qualidades do Aimbirê que Anchieta conhecera em Iperoig, mas por aquilo que mais menosprezavam: a covardia, o tornar-se um espírito malfazejo das matas e, assim, não poder, depois da morte, ir viver com os ancestrais na terra sem males, na yby marã eym.

Uma outra característica do teatro de Anchieta, que o torna singular, é transformar as personagens divinas, mesmo os santos, em seres de carne e osso, a circular pela aldeia em que a representação acontecia. São Lourenço, por exemplo, que no primeiro ato do auto homônimo aparece sendo queimado em uma grelha, como descrevia a Legenda Áurea, no segundo ato, junto com São Sebastião, aparecerá ajudando o Karaibebé, o caraíba voador amigo dos padres, a prender os anhangás Guaixará e Aimbirê e Saravaia. Nesse sentido, o momento que se apresenta a seguir é emblemático: o Karaibebé, personagem do Bem, manda Rore, São Lourenço, e Bastião, São Sebastião, prender e amarrar Aimbirê e Guaixará.

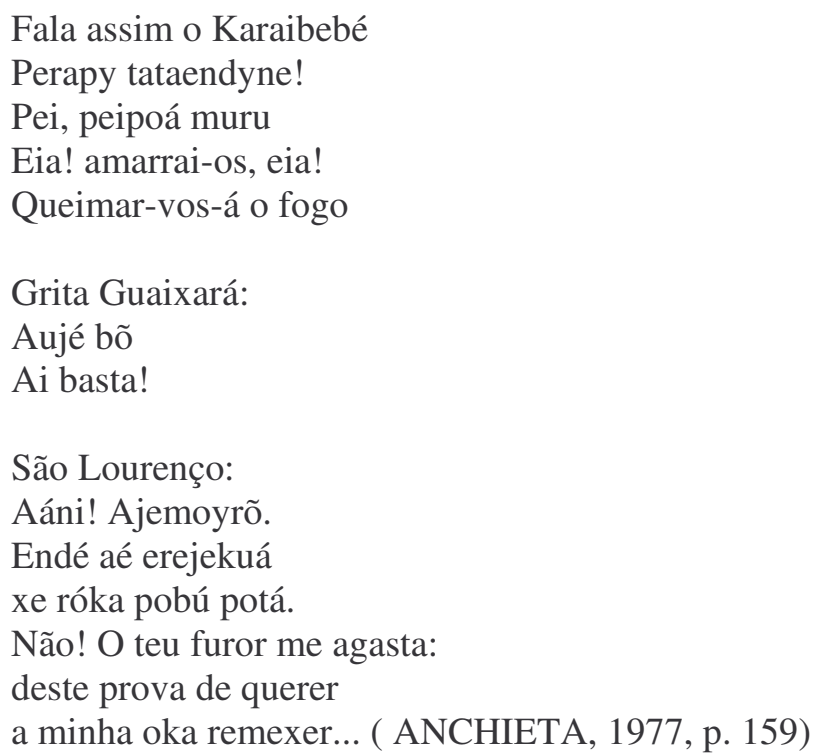

É bom repetir, São Lourenço diz: "deste prova de querer a minha oca remexer". Ora, é exatamente esta a dinâmica da vida dos índios na guerra entre tabas. Os inimigos 
daquela aldeia, Aimbirê e Guaixará, com seu vigia Saravaia, invadem a oca de São Lourenço para fazer prisioneiros, pois Saravaia sai a espiar as ocas, à procura de possíveis prisioneiros. Os protetores da oca, Rore e Bastião, na voz de Aimbirê e Guaixará, Lourenço e Sebastião, na fala do Karaibebê, que são os guardiões, melhores guerreiros, sob o comando do Karaibebé, o caraíba voador, irão capturar os invasores. Livram, assim, a aldeia dos inimigos. No entanto, no final do ato, esses personagens não serão mortos em sacrifícios rituais, o que os tornaria valentes guerreiros, óbvio, mas serão enviados para o fogo, que é a maneira com que os índios acreditavam serem mortos ou espantados os espíritos malignos.

Presos os dois chefes Tamoios, o Karaibebé voltará suas atenções para Saravaia, que ficou escondido. Saravaia tenta corromper o Karaibebé, da mesma forma que os demônios vicentinos tentaram corromper a Alma (cf. VICENTE, 1997); ou como Caliban, personagem de Shakespeare, na peça Tempestade, tenta corromper Stéfano e Trínculo, na ilha de Próspero (SHAKESPEARE, 1911, p. 12). Os autos aqui descritos, porém, são compostos com características próprias da cultura brasileira que se formava. Diz Saravaia para Karaibebé:

\footnotetext{
"ovas de peixes tu queres? A ti darei em resgate. Farinha tu ingeres? Itajubá (pedra amarela, ouro) preferes?” Karaibebé responde rapidamente: "não ouvi tal disparate. Certo de que de alguém escondestes, o roubastes! Em casa de quem pousastes? E que mais coisas furtastes?" (ANCHIETA, 1977, 160)
}

Saravaia, embora diga que conseguiu essas coisas com seu trabalho, diz que trouxe essas três coisas (ovas de peixes, farinha d'água, Itajubá) da casa de cristão, e confessa ter feito isso para comprar cauim. Karaibebé quer devolver o que foi roubado, mas Saravaia diz que bebeu tudo, provavelmente junto com a sogra rabugenta, que bebe muito. E, então, uma nova surpresa: Saravaia, dizendo-se doente, oferece todas as suas peças e seus prisioneiros para Karaibebé, a fim de que este rache a cabeça deles e tome um novo nome, exaltando suas grandezas. Na organização das sociedades tupinambás, era assim que os homens se transformavam em grandes e famosos guerreiros: fazendo prisioneiros, rachando-lhes a cabeça com a itangapema, comendo-lhes a carne e trocando de nome.

O Karaibebé, que significa, literalmente, "homem santo e voador", foi traduzido por "anjo" por quase todos os estudiosos do tupi e das obras de Anchieta; no entanto, no meu entender, faria mais sentido para o espectador indígena representar um caraíba voador amigo dos padres.

Certamente, nesse momento, os prisioneiros, as crianças índias provavelmente, deviam entrar em cena enfileirados e amarrados, pois, quando Karaibebé pergunta por onde ele havia encontrado aquelas presas, este responde que as pegou de surpresa e as atou em uma corda longa, enfileirando-as, dizendo, ainda, serem filhos de índios.

Por fim, Karaibebé prende Saravaia e o leva para junto dos outros dois.

Então, envolvidos pelo drama e pela vitória de Karaibebé, de Lourenço e de Sebastião sobre os três añánga, os espectadores, colonos e nativos, estão preparados para ouvir o discurso de Karaibebé:

Jamais eu me afasto de vocês, estarei sempre guardando-os desse bando, é o que me pediu Tupã. Igualmente os servos do Senhor, São Lourenço, o bondoso, e São Sebastião querem proteger vossa gente do añánga. São Sebastião que foi soldado de guerra, aos Tamoios fortes derrotou, todos foram mortos ao defender suas terras (Paranápucu, Jacutinga, Moroí, 
Sarigueia, Guiriri, Pindoba, Pariguaçu, Curuçá, Miapeí, Tapera Jabebiraci...) que já não mais existem. Lado a lado, os corpos jazem no fundo do mar. Seus bons amigos, os franceses, com o arcabuz foram inúteis diante das flechas de São Sebastião e de São Lourenço (ANCHIETA, 1977, p.162).

Mas, enfim, sugere Karaibebé que os espectadores evitem o que é ruim e desterrem a velha vida - "feio adultério, bebida, mentira, briga, motim, vil assassínio, ferida". Na verdade, propõe que deixem a vida que tinham: a guerra, a cauinagem...e entrem para a nova vida, a cristã.

No final do ato, a vitória total do Karaibebé e dos padres, no palco:

Tasory jandé rayra

Tupã opysyronsápe!

Guaixará toso tatápe!...

Guaixará toso tatápe!...

Guaixará, Aimbirê, Saravaia tose tatápe...

Tasory, oikokatúabo, tekó poxy puéra tyma,

Tupã mokañemeyma,

añánga rausupeábo.

Tasoryb, oputuguábo,

(ANCHIETA, 1977, p. 165).

Os meninos amarrados por Saravaia foram soltos. O Karaibebé diz que os filhos estão libertados, enviando para o fogo Guaixará, Aimbirê e Saravaia. Após esse ato, pede para os espectadores alegrarem-se em vida boa, livrando-se dos vícios, não se afastando de Tupã e afastando-se do añánga. Novamente canta o Karaibebé: "libertouos Tupã! Guaixará vá para o fogo! Guaixará vá para o fogo! Guaixará, Aimbirê, Saravaia vão para o fogo" (Ibidem, p.166). Nesse hibridismo cultural, Tupã — mistura de raio, trovão, chuva e tempestade com ser celestial, Deus - libertou as crianças que estavam prisioneiras, não dos chefes tamoios, não dos índios, mas desses mestiços culturais mistos de espírito malfazejo das matas e do diabo.

Anchieta preparava suas apresentações, tendo em vista alcançar os sentidos do espectador que ele pretendia envolver; afinal, o principal objetivo da missão jesuítica era catequizar os índios. A primeira parte, com São Lourenço morrendo na grelha, seria para os colonos, para os estudantes, ou seja, para aqueles que conheciam a vida do santo. E, como acontecia com autos europeus, poderia ser um ato isolado. A segunda parte do auto aconteceria no aldeamento, pois é toda ela falada em tupi, retrata e critica a vida dos índios, elogiando a vida nos aldeamentos com os padres, com os caraíbas do bem. O terceiro ato seria mais interessante, pois iniciar-se-ia no adro da igreja, junto ao corpo de São Lourenço; iria para o aldeamento, em sua parte em tupi, já que esta parte é a preparação da caça e da possível festa, com o sacrifício dos prisioneiros Décio e Valeriano; e, depois, voltaria para o adro da igreja, porque é falada em espanhol, mas, sobretudo, porque demandaria conhecimentos da vida de São Lourenço, que os índios, mesmo que soubessem espanhol, difícil imaginar que teriam. O final do terceiro ato é falado em tupi pelos índios que prenderam os prisioneiros, os morubixabas Décio e Valeriano, que serão lançados ao fogo (do inferno, ou onde serão assados). O quarto ato é um longo sermão em espanhol e português, o que, não parece fazer muito sentido para espectadores indígenas. 


\section{Considerações Finais}

A Companhia de Jesus nasceu e inseriu-se na religiosidade ocidental em um momento emblemático. Ao mesmo tempo que a poderosa Igreja Católica lutava com os muçulmanos pela retomada de Jerusalém, havia uma crise intensa, ocasionando o cisma e o surgimento de Igrejas dissidentes, reformadas, como a Anglicana, a Luterana, a Calvinista. Além disso, a própria Igreja Católica estava em crise interna, sobretudo com a massa popular, que queria a retomada da experiência espiritual de sacrifícios da Igreja Cristã primitiva, enquanto em Roma havia uma corrupção sem igual (FEBVRE, 1968). Por outro lado havia um novo homem e um novo mundo - desvelados para os europeus por Cristóbal Colón, o portador do estandarte da Cruz no Novo Mundo - a serem conquistados para o Reino de Deus, da Igreja Católica. Os homens da Companhia de Jesus colocar-se-iam, então, como os cavaleiros de Cristo, a conduzir os exércitos da Cruz na luta contra os antigos inimigos, contra os reformadores e na conquista do Novo Mundo e do novo homem.

Inácio de Loyola, o fundador dessa Companhia, criou um instrumento poderoso de formação de seus cavaleiros, um método de aperfeiçoamento das almas na doutrina cristã, os exercícios espirituais, conjunto de regras que conduziam o exercitante para um resgate interior da vida de Cristo, de seu sofrimento e de sua Ressurreição. E, com esse método, habilitava seus soldados na conquista dos homens que estavam fora do rebanho de Deus inicialmente, os homens europeus; mas, com a entrada em cena de Dom João III, influenciado por Diogo da Gouveia, os homens do Novo Mundo entravam no campo de luta dos legionários de Jesus. Para o Brasil, foi destacado Manoel da Nóbrega para liderar esses soldados de Cristo na conquista desse novo homem.

Com ele, vê-se o encontro e o desencontro de culturas e as dificuldades que tiveram os europeus de entender o outro como diferente, de outra cultura e de outra religião. Seres que não poderiam reviver a experiência interior da vida de Cristo, pois, como diz Nóbrega, nenhuma notícia tinham sobre Ele, sendo que apenas São Tomé teria passado por aqui; portanto, os índios não teriam religião. Conclusão apressada que quase provocou uma tragédia. Diante das dificuldades, Nóbrega criaria uma pedagogia apropriada para esse homem das matas, a pedagogia brasílica, plano de estudos que continha uma preocupação realista do Brasil quinhentista.

Diante das dificuldades da realidade nas matas brasileiras, o primeiro provincial do Brasil, mesmo contrariando a Constituição da Companhia, dedicou-se à construção de casas de bê-á-bá e a coletar recursos por todos os lados para a mantença dos meninos órfãos, índios ou mestiços (FERREIRA JÚNIOR; BITTAR, 2007). As normas da Constituição estabeleciam que só poderiam ter rendas os Colégios da Companhia, para a formação de quadros de clérigos. Nóbrega, com seu jeito pragmático, afinal, não tinha condições de evangelizar, sem casa, para meninos que não tivessem renda; arranjou inimigos, Luiz da Grã, Miguel de Torres, e pode-se incluir o Bispo Pero Leitão. Mas aliouse a gente importante, entre eles o poderoso governador Mem de Sá, com quem ampliou o poder temporal e espiritual da Companhia de Jesus e do próprio reino português na Colônia, que ia perdendo terreno para os franceses. Teria conquistado o Rio da Prata, a cidade do Paraguay, se tivesse encontrado gente disposta a ir para lá, e se isso não causasse um conflito com Sua Alteza, o rei de Portugal.

Anchieta, por sua vez, penetrou fundo na cultura, na religião, na sociedade indígena e tentou transformá-la de dentro. Utilizando, sobretudo, o teatro, criou tipos característicos dessa sociedade e assim pôde criticar os costumes, a moral, a religião e ensinar uma nova moral, uma nova religião para eles, a cristã. Anchieta morreu em 1597; dois anos após, em 
1599, seria concluída a Razão de Estudos, a Ratio Studiorum, que se tornaria obrigatória para todos os colégios da Companhia. Seu método pedagógico, portanto, também era a "pedagogia brasílica", que não tinha regras, normas, e que, por vezes, fazia ele também, como Nóbrega, desafiar a própria Constituição da Companhia.

A luta interna da Companhia entre a obediência cega às normas da Constituição aprovada em 1558, que dificultava a catequese e a própria missão jesuítica, defendida aqui pelo segundo Provincial, Luiz da Grã - e a desobediência a elas, que produzia resultados, parece ter sido resolvida a favor de Nóbrega e Anchieta. O primeiro manteve seu projeto de expansão temporal da Companhia e as casas e os colégios para meninos da terra, órfãos, mestiços, pois o veredicto favorável sobre a manutenção das casas de Bê-á-bá foi exarado pela própria lavra do segundo Geral da companhia, Diogo Laines, em 1561 (FERREIRA JÚNIOR; BITTAR, 2007, p. 37), mesmo Nóbrega não sendo mais o provincial da Companhia, substituído justamente por seu rival nessa querela.

Anchieta, por sua vez, fez teatro por aqui, não somente em português, como em tupi, o que contrariava as regras eclesiásticas romanas. Além do quê, os santos, São Lourenço e São Sebastião, foram transformados em guerreiros indígenas a caçar os inimigos, inclusive com arco e flecha. E, para não restar dúvidas de que Anchieta lançou mão de todos os recursos possíveis em sua "pedagogia brasílica" para o aperfeiçoamento de almas na doutrina cristã, bastaria dizer que ele criou A paixão de Cristo em tupi, fazendo com isso um híbrido do sacrifício cristão com personagens próprias das matas brasileiras, como Tupã e Anhangá.

Conclui-se, pois, o artigo, com o trecho inicial de A paixão de Cristo em tupi. Mestre e discípulo dialogam:

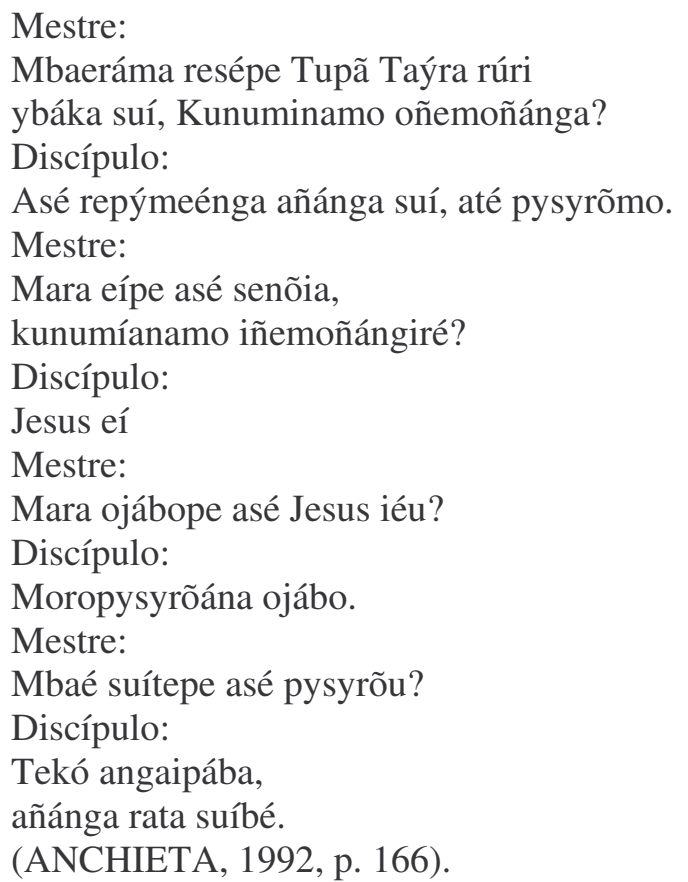

Pergunta o mestre para o seu discípulo: "Para que veio do céu o filho de Tupã, fazendo-se criancinha"? Responde o discípulo: "Para resgatar a gente do añánga e para nos salvar". Pergunta o mestre: "Que diz a gente depois que se fez criancinha"? Responde o discípulo: "Diz Jesus". Pergunta o mestre: "Dizendo a gente Jesus, o que diz"? Responde o discípulo: "Diz que veio para salvar os homens". Pergunta o mestre: "Mas do que salva a gente"? Responde o discípulo: "Das coisas más, e do fogo do añánga" (Ibidem). 
O filho de Tupã, Jesus, desceu do céu para salvar os homens, a gente, do fogo dos añánga, é o que dizem mestre e discípulo nessa Paixão de Cristo, em tupi. Tupã era o vocábulo que os índios nomeavam o trovão, o raio, a tempestade, a chuva. Como eles não tinham um Deus, nem deuses etéreos e, sendo Tupã um fenômeno celeste, os padres adaptaram esse vocábulo para "Deus", que, no entanto, trazia em suas letras mais de mil anos de história em atributos e significações. O filho de Tupã veio do céu para salvar a gente do añánga, que é o vocábulo com que os índios nomeavam, com muito temor, os espíritos malfazejos das matas. Espíritos esses de índios covardes que não mataram seus inimigos, não vingaram seus parentes e que, ao morrer, ficavam vagando pelas matas, encarnados nos jaguares, nas cobras cascavéis, entre outras feras, a perseguir, afogar e matar "os que estão pelo caminho", como diz Aimbirê no Auto da Pregação Universal.

\section{REFERENNCIAS}

AGUILAR, Jurandir Coronado. Conquista espiritual: a história da evangelização na Província Guairá na obra de Antonio Ruiz de Montoya, S.I (1585-1652). Analecta Gregoriana. Roma: Editrice Pontifícia Universitá Gregoriana, 2002.

ANCHIETA, José de. Cartas: informações, fragmentos históricos e sermões. Belo Horizonte: Itatiaia; São Paulo: Editora da Universidade de São Paulo, 1988a.

Poema da Bem-Aventurada Virgem Maria, Mãe de Deus. Originais latinos acompanhados de tradução em verso alexandrino. Introdução e anotações ao texto por Pe. Armando Cardoso, S.J. São Paulo: Loyola, 1988b (Tomos I e II).

. Artes de gramática da língua mais usada na costa do Brasil. Apresentação de Dr. Carlos Drummond. Aditamentos de Pe. Armando Cardoso, S. J. São Paulo: Loyola, 1990.

. Doutrina Cristã. Introdução, tradução e notas de Pe. Armando Cardoso, SJ. São Paulo: Edições Loyola, 1992. (Tomos I e II).

Teatro de Anchieta. Obras completas. Originais acompanhados de tradução versificada, introdução e notas de Pe. Armando Cardoso S.J. São Paulo: Loyola, 1977.

Teatro. Seleção e tradução do tupi de Eduardo Navarro. São Paulo: Martins Fontes, 1999.

BAKHTIN, Michail. A cultura popular na Idade Média e no Renascimento: o contexto de François Rabelais. Tradução de Yara Frateschi. 4. ed. São Paulo: Hucitec; Brasília: EdUNB, 1999a.

- Marxismo e filosofia da linguagem. Prefácio de Roman Jakobson. Apresentação de Marina Yaguello. Tradução de Michel Lahus e Yara Frateschi Vieira. 9. ed. São Paulo: Hucitec, $1999 b$.

BITTAR, M. O estado da arte em história da educação brasileira após 1985: um campo em disputa. In: LOMBARDI, J. C.; SAVIANI, D.; NASCIMENTO, M.I.M. (Org.). Navegando pela história da educação. Campinas: HISTEDBR, 2006. p. 1-24. Disponível em: $<$ http://www.histedbr.fae.unicamp.br/navegando/index.html>. Acesso em: set. 2010.

BITTAR, M; FERREIRA, A. A pesquisa em história da educação colonial. In: PAIVA, J. M.; BITTAR, M.; ASSUNÇÃO, P. (Org.). Educação, história e cultura no Brasil colonial. São Paulo: Arké, 2007.

BOSI, Alfredo. Dialética da colonização. São Paulo: Companhia das Letras, 1992. 
CONSTITUIÇÕES da Companhia de Jesus e normas e regras. São Paulo: Loyola, 1997.

EDELWEISS, Frederico G.. Estudos tupis e tupi-guaranis. Rio de Janeiro: Brasiliana, 1969.

FERNANDES, Florestan. A função social da guerra na sociedade tupinambá. 2. ed. São Paulo: Pioneira; Editora da Universidade de São Paulo, 1970.

A organização social dos tupinambá. São Paulo: Instituto Progresso Editorial, [s.d.].

FERREIRA JÚNIOR, Amarílio; BITTAR, Marisa. Pluralidade lingüística, escola de bê-a-bá e teatro jesuítico no Brasil do século XVI. Educação \& Sociedade, Campinas, SP, v. 25 n. 86, p. 472-482, set.-dez. 2004. Disponível em <www.scielo.br>. Acesso em: set. 2010.

FERREIRA JÚNIOR, Amarílio; BITTAR, Marisa. Casas de bê-a-bá e colégios jesuíticos no

Brasil do século 16. In: Em Aberto, Brasília, v. 21, p. 33-57, [sd]. Disponível em:

<http://www.rbep.inep.gov.br/index.php/emaberto/article/viewFile/1240/1108>. Acesso em: out. 2010.

. A arqueologia do saber. Tradução de Luiz Felipe Baeta Neves. 6. ed. Rio de Janeiro: Forense Universitária, 2002.

HANSEN, João Adolfo. A escrita da conversão. In: COSTIGAN, Lúcia Helena (Org.).

Diálogos da conversão: missionários, índios, negros e judeus no contexto ibero-americano do período barroco. Campinas: Editora da Unicamp, 2005.

HAYASSHI, Maria Cristina Piumbato Innocentini et al. História da educação brasileira: a produção científica na biblioteca eletrônica SCIELO. Educação \& Sociedade, Campinas, SP, v. 29, n. 102, p. 181-211, jun./abr. 2008. Disponível em: <www.scielo.br>. Acesso em: set. 2010 .

HERNANDES, Paulo R. Os Exercícios Espirituais e o teatro. In: PAIVA, J. M.; BITTAR, M.; ASSUNÇÃO, P. (Org.). Educação, história e cultura no Brasil colonial. São Paulo: Arké, 2007. $2008 \mathrm{a}$.

O teatro de José de Anchieta: arte e pedagogia no Brasil colônia. Campinas: Alínea,

Os Exercícios Espirituais e a Companhia de Jesus. Revista do HISTEDBR on-line, n. 30, 2008b. Disponível em: <www.histedbr.fae.unicamp.br/revista/edicoes30/art18_30.pdf>. Acesso em: set. 2010.

HOLANDA, Sérgio Buarque de. Raízes do Brasil. 4. ed. Brasília: Editora Universidade de Brasília, 1963.

LACOUTURE, Jean. Os jesuítas 1: os conquistadores. Tradução de Ana Maria Capovilla. Porto Alegre: L\&PM, 1994.

LEITE, Serafim S. J. Novas cartas jesuíticas: de Nóbrega a Vieira. São Paulo, Rio, Recife, Porto Alegre: Companhia Editora Nacional, 1940.

Cartas dos primeiros jesuítas do Brasil -1538-1553. São Paulo: Comissão do IV centenário da cidade de São Paulo, [1954a]. v. 1.

Cartas dos primeiros jesuítas do Brasil — 1553-1558. São Paulo: Comissão do IV centenário da cidade de São Paulo, [1954b]. v. 2.

História da Companhia de Jesus no Brasil: século XVI - o estabelecimento. Belo Horizonte: Itatiaia, 2000a. v. 1.

História da Companhia de Jesus no Brasil: século XVI - a obra. Belo Horizonte: Itatiaia, 2000b. v. 2. 
LOYOLA, Inácio. Exercícios espirituais. Orientação da tradução e anotações de Pe. Géza Kövecses S. J. 3. ed. Porto Alegre, 1966.

Diário espiritual de Inácio de Loyola. Tradução e notas de Pe. Armando Cardoso, S.J. São Paulo: Loyola, 1977.

. Autobiografia de Inácio de Loyola. Tradução e notas de Pe. Armando Cardoso, S.J. 3. ed. São Paulo: Loyola, 1987.

METRAUX, A., A Religião dos Tupinambás. Prefácio, Tradução e Notas do prof. Estevão Pinto São Paulo: Companhia Editora Nacional, [sd].

MILLER, René Fülöp. Os jesuítas e o segredo de seu poder. Tradução de Alvaro Franco. Porto Alegre: Livraria do Globo, 1935.

MONUMENTA IGNACIANA. Sanct Ignatii de Loyola: epistolae e instruciones. Madri: Gabriele Lopes Del Horno, 1909.

NAVARRO, João de Azpilcueta et al. Cartas Avulsas, 1559-1568. Belo Horizonte: Itatiaia; São Paulo: Editora da Universidade de São Paulo, 1988.

NÓBREGA, Manoel da. Cartas jesuíticas 1. Belo Horizonte: Itatiaia; São Paulo: Editora Universidade de São Paulo, 1988.

PAIVA, José Maria de. Colonização e catequese. São Paulo: Autores Associados; Cortez, 1982.

RABELAIS, François. Gargântua e Pantagruel. Tradução de David Jardim Júnior. Belo Horizonte: Itatiaia, 2009.

SHAKESPEARE, William. The tempest; Hamlet, Prince of Denmark. In: CLARK, W. G.; WRIGHT, W. A. (Ed.). The complete works of William Shakespeare. New York, Grosset \& Dunlap, 1911.

TODOROV, Tzvetan. A conquista da América: a questão do outro. Tradução de Beatriz Perrone-Moisés. 4. ed. São Paulo: WMF Martins Fontes, 2010. (Biblioteca do pensamento moderno).

VAINFAS, Ronaldo. A heresia dos índios: catolicismo e rebeldia no Brasil colonial. São Paulo: Companhia da Letras, 1995.

VASCONCELOS, Simão de. Crônica da Companhia de Jesus. Introdução de Serafim Leite. 3. ed. Petrópolis: Vozes, 1977.

VICENTE, Gil. TRÊS AUTOS: Da Alma; da Barca do Inferno; de Mofina Mendes. Introdução de Leodegário A. de Azevedo Filho. Adaptação de Walmir Ayala. Rio de Janeiro: Ediouro; São Paulo: Publifolha, 1997.

. Obras primas do teatro vicentino. Edição organizada por Segismundo Spina. 4. ed. São Paulo: Difel, 1983.

WRIGHT, Jonathan. Os jesuítas: missões, mitos e histórias. Tradução de André Rocha. Rio de Janeiro: Relume Dumará, 2006. 
Notas

${ }^{1}$ Provavelmente, porque só temos a resposta de Favre a essa carta.

${ }^{2}$ Em carta de 1556 para Inácio de Loyola, que já tinha morrido, escreve Nóbrega que a "Constituição este ano de 1556 nos fez Nosso Senhor mercê de no-las mandar pelas quais entendemos não devemos ter carrego nem gente para doutrinar na fé; ao menos em nossa conversação tão bem não poderem os Irmãos ter bens temporais nenhuns, se não for colégio" (NÓBREGA, 1988, p. 140) Para transformar a casa de São Paulo de Piratinin em Colégio, não dá, afinal o ferreiro que trabalha nela é velho e doente, as vacas foram adquiridas para os meninos da terra e são suas, e a esmola D’El Rei é incerta. Se for casa, não dá para se viver de esmolas naquele lugar, pois a gente é miserável (Ibidem).

${ }^{3}$ O Nheengatu, para Edelweiss (1969), foi a transformação do tupi e da língua geral, língua mais usada na costa brasileira, ao longo do tempo. Apareceria somente no final do século XVII e consolidar-se-ia como termo referente como dialeto, ou língua, no século XVIII, por questões de desdobramento histórico e cultural da língua. O termo "nheengatu" do século XVI significaria "boa fala". A fala dos pajés, por exemplo. Para mais informações sobre esse assunto, remeto o leitor ao livro de Frederico Edelweiss, Estudos tupis e tupiguaranis, sobretudo aos capítulos "Dialeto Nheengatu" e "O termo Nheengatu".

Artigo recebido em: 12/08/2010

Aprovado em: 5/9/2010 